\title{
Towards a Marxist Critique of the Political Economy of Migration and the Media
}

\author{
Siyuan Yin
}

School of Communication, Simon Fraser University, Burnaby, Canada, siyuan_yin@sfu.ca

\begin{abstract}
The global outbreak of COVID-19 has exposed varied ways that systemic inequality shapes people's lives. This article pays particular attention to migrant populations. While mainstream media and political discourse tend to construct migration as a problem to be addressed or even the cause of social problems, the article contends that migration should be understood as an immanent part of capitalist uneven development, entwined with patriarchy and colonialism. The post-modern approach within media and communication scholarship on migration fails to challenge media's constitutive role in patriarchal and racial capitalism which fundamentally shapes the process and consequences of migration. Drawing on a Marxist political economy perspective, I analyse the two cases of global transnational migration and internal migration in China and argue that media and communication studies should account for the material disparity and class divisions among migrant groups and look for transformative forces that work against unequal power structures.
\end{abstract}

Keywords: migration, media, class, migrant workers, elite migrants, capitalist globalisation, inequality

\section{Introduction}

As the global outbreak of COVID-19 continues to affect people's lives in various ways, it particularly exposes how systemic inequalities exacerbate the impact of the pandemic on underprivileged groups. One of the realities that the pandemic makes evident is that migration not only involves different types of migrant populations but entangles the huge disparities between them. While privileged migrant groups including tourists, businessmen, and middle-class immigrants travel for leisure or profit-making or emigrate for desirable lifestyles, migration serves as one of very few means of survival for underprivileged migrants such as migrant workers and refugees. The challenges that COVID-19 has brought to human mobility plainly reveal such disparities. On one hand, stranded nationals from developed countries can rely on their governments to take them back home. Affluent groups can afford the absurdly high cost of international travel during the pandemic. For instance, the Canadian government has sent planes to bring 20,000 stranded Canadian tourists in South America, Europe, and Asia back home. ${ }^{1}$ Facing limited international flights, Chinese businessmen, tourists, and international students abroad turned to chartered planes and spent hundreds of thousands of dollars flying back to China. ${ }^{2}$

${ }^{1}$ Canadian news media have reported stranded Canadian tourists abroad being brought home by the government: https://www.cbc.ca/news/politics/stranded-canadians-abroad-foreign-affairs-1.5541682

2 Chinese news media have reported these cases: http://www.chinanews.com/gn/2020/0201/9074713.shtml; https://finance.sina.com.cn/china/dfij/2020-07-14/dociivhuipn2889429.shtml; https://www.thepaper.cn/newsDetail forward 7049790 
On the other hand, disadvantaged migrants, especially migrant workers, are among the most vulnerable groups affected by the epidemic. In the past months of the national lockdown in India, due to the shutdown of workplaces and transport, millions of rural migrant workers have been left with few choices but to leave the big cities with little money and food and walk thousands of miles back to their home villages. ${ }^{3}$ By May 2020, 17,758 low-income migrant workers from South Asia in Singapore living in dormitories with very poor housing conditions and hygiene had been infected by COVID19 , taking up $88 \%$ of the total number of confirmed cases in the country (Koh 2020). Examples like these are numerous worldwide.

Despite the diversity of migrant populations, Western mainstream media predominately construct migration as people moving from less developed countries to more developed ones. Along with political discourse, media discourse highlights issues regarding immigrants and refugees in order to reinforce the salience of "migration problems" in Western countries (Gutiérrez Rodríguez 2018; Khiabany 2016). Media and communication scholarship on migration reveals the dichotomised representation of immigrants and refugees in mainstream media. Racist and xenophobic discourse and stereotypical representations in the media exacerbate the social exclusion and marginalisation of immigrants and refugees in Western countries (Bauder 2008; Campani 2001; Gale 2004; Orgad 2012; van Dijk 2000). Favourable tones in media either emphasise the economic contribution of immigrants (Bauder 2006; Lawlor and Tolley 2017) or heavily resort to sensational reports to appeal to public sympathy on the sufferings of immigrants and refugees as a humanitarian crisis (King and Wood 2001; Mummery and Rodan 2007). Media scholars have also addressed the uses of ethnic media and ICTs among diaspora groups in their formations of a new identity, culture, and communities living in Western countries (Fleras 2009; Georgiou 2006; 2013; Hegde 2016; Katz 2010; Yoon 2018).

Media scholarship on the social inclusion/exclusion and identity politics of immigrants and refugees is not sufficient to contest the mainstream media discourse, which constructs migration as a problem to be solved. To question unequal power structures that shape the process and consequence of migration and the role of media in the process, a Marxist political economic approach, which goes beyond a postmodern paradigm, is much needed in migration and media studies. In the fifth edition of the book The Age of Migration, Castles et al. $(2014,26)$ define migration as a mass movement of human populations, urging that migration should be viewed "as an intrinsic part of a broader process of development, globalisation, and social transformation, not a problem to be solved". From a Marxist approach, I further argue that migration should be understood as an immanent part of capitalist development and globalisation, entwined with patriarchal and racial power hierarchies. Mainstream media discourses of migrant groups, regardless of being negative or positive, reinforce the view of migration as a problematic outcome of globalisation. Negative discourses present migration as the causes and sources of social conflicts and problems. Positive representations rationalise the worthiness of the migrant population by highlighting their contributions to destination countries. Both ways reproduce the dichotomy of 'us'; that is, entitled citizens; and 'them'; that is, others whose acceptability depends on how much benefit 'they' can

${ }^{3}$ The BBC's news article on Indian rural migrants' suffering situation during Covid-19: https://www.bbc.com/news/world-asia-india-52086274 
bring to 'us'. Meanwhile, a symbolic lens that prioritises the cultural identity of immigrants and diasporas is not adequate to capture the material disparities among migrant populations.

This article analyses two cases: transnational migration in capitalist globalisation and the class-divided internal migration in China. Historically, the transnational mass movement of populations is the consequence and a constitutive part of European countries' capitalist and colonial expansion. The transatlantic enslaved people and European settler colonials manifest the stark inequality embedded in the process of migration. In the contemporary era, the enduring class, racial, and gender inequalities that designate transnational migration reside in the huge material disparity between elite migrants and underprivileged immigrants, temporary migrant workers, and refugees. Internal mass rural-to-urban migration is also a product of industrial growth to facilitate capital accumulation, as can be seen in England from the 18th to the 20th century and in recently emerging countries, such as China and India, which have been active actors in neoliberal globalisation in the past several decades. China's economic reform since the 1980s has created a great number of rural-to-urban migrant workers to fulfil the demand for cheap labour exploited by transnational and domestic capital. While the market-driven economy and discriminating Party-state policies have disenfranchised rural migrants, the reform has benefited the urban middle-class. Both of the groups are major constituents of the country's mass internal migration.

The conspicuous inequality among class-divided internal and transnational migrant groups is in sharp contrast to mainstream media's incomplete account of migration and the distorted view that accuses migration as the cause of social problems. A Marxist political economic critique takes a holistic perspective to manifest the mutually constitutive relationship between profit-driven media and the capitalist system (Mosco 2009). By presenting migration as a problem to be solved, profit-driven media circumvent any critique of capitalist domination. Discussions about the inequality between privileged and underprivileged migrant groups as the result of capitalist uneven development are largely absent in media. Neither the stereotypical nor the favourable media discourse about underprivileged migrants addresses labour exploitation. A Marxist critique of media also seeks the actual and potential role of media and information technologies in social struggles and the establishment of alternatives (Fuchs 2014). The struggle should start from a workers' standpoint. This standpoint can downplay the differences between working-class migrant groups, such as domestic workers, rural-to-urban migrants, temporary migrants, and local working people, highlighting their shared class position in the global capitalist economy. The political identity of workers may cultivate solidarity between transnational and internal migrant workers, the latter of which constitute a large portion of the migrant population but are often overlooked in popular discourse about migration.

\section{Media Scholarship on Immigrants and Refugees}

Scholarship on migration and media in the Western context has extensively documented how media shape migrant populations' lives, with an emphasis on immigrants and refugees. King and Wood's edited column "Media and Migration" (2001) summarises three ways that media shape the process of migration. First, mediated images from and about destination countries, including films, advertisements, and TV programmes, can be a source of information for potential migrants. Second, media construction and representation of migrants in destination countries play a vital role in constituting the conditions of migrants' social exclusion and inclusion. Third, media consumption and uses of ICTs shape the formation of diasporic identities and transnational 
communities. The majority of studies fall into the last two strands. Numerous empirical studies demonstrate that media represent immigrants in dichotomised ways, negative or positive. Negative representations portray immigrants as undesirable others. The criminalisation of migrants by media is one notable trend. For instance, immigrants and refugees are very often reported by news media as criminals and as reasons for high crime rates in Western countries, including Italy (Campani 2001), the UK (van Dijk 2000), Australia (Gale 2004), Canada (Bauder 2008) and the US (Orgad 2012), just to name a few. Racist and xenophobic ideologies underpin the negative media discourse of immigrants and refugees. Analysing migrants and media in Italy, Campani (2001) reveals that the media highlight the images of immigrants and refugees as subordinate groups, reinforcing the groups' marginality and exclusion. With an example of a television advert targeting immigrants from Cameroon and Nigeria, Orgad argues that Western media representation of immigrants' experiences as nightmares is intentionally designed to discourage potential immigrants from migrating (2012). Hargreaves's (2001) study on media and ethnic relations suggests that the systematic underrepresentation of ethnic minorities in French mainstream media exacerbates their social exclusion from French society.

Favourable media discourse either highlights the economic contribution of immigrants to destination countries or calls for public sympathy towards disadvantaged migrants such as refugees. For instance, skilled immigrants in Canada are portrayed by media and immigration policy as desirable and beneficial to the development of the national economy (Bauder 2006; Lawlor and Tolley 2017). Such celebratory discourse often appears in Western media adopting a favourable attitude towards immigration. Humanitarianism is the other common theme in positive media representation. Sensational reports on the sufferings of illegal immigrants invoked public sympathy towards the group in the UK and France (King and Wood 2001). Australia is depicted by its mainstream media as a humane nation with moral obligations to help and protect refugees who escape from oppression in their home countries (Mummery and Rodan 2007). But these seemingly affirmative and sympathetic tones still reinforce the "us and them" binary and justify the advantageous positions of destination countries and their moral superiority.

A great number of studies have demonstrated varied media practices and uses of ICTs by migrant populations to create new spaces, social relations, identities, and communities. The mediated process and experience of migration transcends the traditional boundary of the nation-state. Emphasising a transnational perspective, Georgiou (2006; 2013) and Hegde (2016) have argued that mediation constitutes the process and realities of migration. Media become part of the everyday life of the diaspora to forge transnational networks and communities: these stand for a co-existence of the global, local, and national (Georgiou 2006). The presence and prevalence of digital media further facilitate the formation of transnational publics (Hegde 2016). Immigrants and diaspora are connected to both their countries of origin and their destinations, and media mediate such connections. For example, first-generation immigrants tend to consume media from their home countries while younger generations often form new identities from hybrid culture and media receptions (King and Wood 2001). Empirical studies have shown that immigrants interact with various forms of ethnic media to negotiate their cultural identities and sense of social belonging in Western countries, such as multicultural media and immigrants in Canada (Fleras 2009; Ahmed and Veronis 2017; Yoon 2018), Latino immigrants and their blended uses of new and traditional media in the US (Katz 2010), Muslims and ethnic media in France (Croucher, Oommen 
and Steele 2009), and Chinese immigrants and online homeland and ethnic media in New Zealand (Yin 2013), among many others.

To address the role of media and digital technologies in shaping the social inclusion/exclusion and identity politics of immigrants and refugees ironically reinforces the media discourse of constructing migration as a problem to be solved, without accounting for the unequal power structures, such as capitalism, imperialism, and colonialism, which designate the process and outcome of migration and migrant populations' situations. Studies on the formations of new identity, culture, and communities through practices and uses of media and ICT fall into Harvey's critique of a postmodernist approach of ghettoising and othering (1989). Postmodern thoughts, as Harvey argues,

accept the reifications and partitioning, actually celebrating the activity of masking and cover-up, all the fetishisms of locality, place, or social grouping, while denying that kind of meta-theory which can grasp the political-economic process that is becoming ever more universalizing in their depth, intensity, reach and power over daily life $(1989,117)$.

The postmodern approach entails a blind spot in addressing the larger political-economic process that shapes migration and produces inequality among migrant populations.

\section{A Marxist Political Economic Critique of Migration and Media}

To go beyond a postmodern paradigm that fails to challenge the unequal power structure that shapes circumstances of diverse migrant populations and their relationship with media, a Marxist political economic approach is much needed. Marx's critique of capitalism exposes labour exploitation as a brutal form of capital accumulation and class domination as a fundamental characteristic of the capitalist system (1867/2013). Migration as the mass movement of population is both a consequence and a component of capitalist uneven development and expansion. Enslaved people's forced transatlantic movement, European settlers' colonial migration, contemporary elites' and underprivileged migrant workers' transnational migration, and rural-to-urban internal migration are all manifestations demonstrating that the inequality and domination of capitalism and its colonialist and imperialist expansion not only shape the process of migration but are reproduced through migration.

A Marxist political economy of communication takes a holistic approach towards the mutually constitutive relationship between commercial media and capitalism (Mosco 2009): "A Marxist communication theory analyses communication in the context of the dialectic of class and domination and of capitalism as a societal totality that is grounded in the logic of accumulation and creates inequality" (Fuchs 2020, 12). Profit-driven mainstream media underpin the hegemony of capitalism. For instance, analysing the moral panic about asylum seekers in Germany, Gutiérrez Rodríguez reveals that the media and politician's discourse about the "European migration crisis" ignores "an entangled history of global exploitation, imperial oppression, and capitalist expansion" $(2018,19)$. Similarly, Khiabany points out the lack of discussion of capitalism and imperialism in the mainstream media reports on refugees (2016). The following discussions address the inequality embedded in transnational and internal migration, along with capitalist uneven development and globalisation and how mainstream media sustain the hegemonic power structure. 


\subsection{Transnational Migration Shaped by Capitalism, Colonialism, and Patriarchy}

Transnational migration has been profoundly shaped by capitalist countries' imperialist and colonial expansion. While Western media and politicians frame migration as a phenomenon that emerged in the 1945 post-war era and accelerated in 1970s globalisation (Gutiérrez Rodríguez 2018), transnational migration has long been embedded in the process of European capitalist modernisation. The Atlantic slave trade from the 16 th to the 19th century forced millions of African people to the Americas as enslaved labourers on plantations in the production of cotton, sugar, and other commodities. The wealth accumulated in the forced migration and brutal exploitation of enslaved people's labour created the conditions for industrialisation and fuelled the rising power of the capitalist class in Europe. Marx has incisively revealed the essential role of the brutal slave trade and colonisation in the primitive accumulation of capitalism that "the treasures captured outside Europe by undisguised looting, enslavement, and murder, floated back to the mother-country and were there turned into capital" (1867/2013, 918). Meanwhile, Europeans have migrated across oceans and continents to the Americas and Pacific Islands over the past centuries, depriving indigenous and aboriginal people of their land and even their lives. The settler colonialism and the settlercolonial power of European migrants, in its stark contrast to enslaved people's forced migration, thoroughly expose how migration embraces inequality and violence in its process and consequence.

In contemporary neoliberal capitalist globalisation, transnational migration continues to entangle a huge material disparity among migrant groups. The consolidation of the patriarchal sexual division of labour, postcolonial racial hierarchy, and uneven capitalist development lead to such disparity. Working-class women from the global South fill in the labour demand of care industries in the global North and prosperous areas, as for Filipina domestic workers in Hong Kong (Constable 2017), Singapore (Wong 1996; Marti 2019) and Canada (Grandea and Kerr 2010; Fudge 2011); migrant women from Africa, South and Southeast Asia, and Eastern Europe working in middle-class and upper-middle-class households in Western, Northern and Southern Europe (Anderson 2004); and undocumented immigrant women working as nannies and maids in US households (Romero 2013). These women lack legal protection of their workers' rights and often face unfair treatment or even abuse and violence. The exploitation of migrant domestic workers' labour and what Hochschild $(2014,134)$ terms "emotional surplus value" is underpinned by the interlocking system of inequalities where capitalism is deeply intertwined with patriarchy and racism (Hardt and Negri 2018). The increasing number of temporary migrant workers is another manifestation of the transnational labour migration: these include seasonal migrant farmers in Canada (Basok 2003), Arab and Asian construction workers in the Middle East and North Africa (Kapiszewski 2016), and South Asian migrant workers in Singapore (Yea, Mohsin and Fordyce 2014), to name a few. Without proper policy or laws to protect their labour rights, temporary migrant workers are in a vulnerable position, easily subject to exploitation, with low wages and poor working and living conditions. Compared with less developed countries where rural migrants form the cheap labour force, in developed countries, transnational working-class migrants fill capital's need for profit-making.

On the other hand, the rising number of transnational elites has shown the longlasting class inequality embedded in transnational migration. The formation of transnational class power has witnessed the restoring power of economic elites in developed capitalist countries and the creation of new economic elites in developing countries. As Harvey $(2007 a, 29)$ keenly points out, "the neoliberal globalization has been a reorganization of international capitalism to re-establish capital accumulation and to 
restore the power of economic elites". Globally, a new upper-class economic power has arisen in the sectors of computing, the Internet, media, pharmaceuticals, transportation, and retailing (Harvey 2007a; 2007b). The privileged transnational migrants are constituted by these elites, including economic emigrants from and to developed countries. For instance, about 2.8 million Canadians live abroad, with over $50 \%$ of this population settling in developed capitalist countries and areas, such as the US, UK, Hong Kong, and Australia. ${ }^{4}$ These emigrants are often high-skilled professionals in medical care, academy, IT, and finance. ${ }^{5}$ The majority of high-paid programmers in Silicon Valley are Indian and Chinese immigrants graduating with a US degree. The internalisation of US higher education not only becomes one of the crucial means of migration for transnational elites but also serves as key sites to cultivate what Ong $(2006,140)$ terms "borderless entrepreneurial subjects". Management, finance, and electrical engineering are the most popular majors in Western universities among international students, and these students are usually from at least middle-class families who can afford the tuition and living costs of studying abroad. Temporary elite migrants are mainly real estate investors, businessmen, and tourists. In the past few years, investors from mainland China have poured thousands of millions of dollars into real estate markets in Western metropolitan cities, such as New York City, Vancouver, London, Sydney and Auckland. Businessmen and tourists from developed and developing countries travel around the world. Southeast Asia, Thailand and Latin America have remained popular tourist destinations for Western travellers. Numbers of Canadian 'snowbirds' travel to the US and Central and Latin America every winter. Chinese tourists make millions of overseas trips each year. Southern European countries, such as Spain and Portugal, become attractive places for Western European retirees to settle. In parallel with working-class migrants serving as the cheap labour force in capitalist global production, elite migrants are ideal consumers for the capitalist global economy.

Mainstream media circumvent addressing the material inequality among transnational migrants in the global capitalist system and counteract any cultivation of anticapitalist solidarity. By modelling the public understanding of transnational migration as if migration merely encompasses people from less developed countries or areas affected by wars and disasters moving to developed countries seeking better lives and safer living environments, mainstream media in Western capitalist countries pay far less attention to the material disparity among immigrant populations and the varied groups migrating from developed countries to the rest of the world. Meanwhile, the 'them' and 'us' binary reinforced in Western media reports on immigrants fill in the xenophobic discourse which fosters and strengthens the nationalist sentiment. The nationalist sentiment differentiates immigrant workers from domestic working people. Such nationalism, as Fuchs $(2018,530)$ argues, "is an ideology that constructs a fictive national unity of capital and labour by opposing the nation to a foreign enemy and thereby distracts attention from how social problems are grounded in class, exploitation, and domination". In the Communist Manifesto, Marx and Engels (1848/1992, 23) once predicted that "national differences and antagonisms between peoples are daily more and more vanishing, owing to the development of the bourgeoisie [...] to the

${ }^{4} \mathrm{~A}$ news report on Canadians living abroad from CBC (Canadian Broadcasting Corporation): https://www.cbc.ca/news/canada/estimated-2-8-million-canadians-live-abroad-1.790218

5 The Asia Pacific Foundation of Canada published a report on Canadian overseas in 2011, titled "Canada's global asset": https://www.asiapacific.ca/sites/default/files/canadians abroad final.pdf 
world market [...] and in the conditions of life corresponding thereto. The working men have no country". Nationalism, as the false consciousness of the working class, prevents the latter from forming solidarity with workers from other countries. In contemporary neoliberal globalisation dominated by financial capital, the disempowered working people in capitalist countries are fed by capitalism with scapegoats: namely, immigrants, often along with women and racial minorities (Harvey 2018). The structural inequalities of capitalism are displaced onto migration, especially immigrant workers and refugees. A Marxist political economic critique calls for the urgent need to challenge dominant ideologies about migration reproduced in media and popular discourse that sustain capitalist power structure.

\subsection{Class-Divided Internal Mass Migration}

Capitalist development has also compelled internal mass migration in historical and present conjunctures. The "expropriation of the agricultural population from the land" served as a key process in primitive capitalist accumulation in industrialising England (Marx 1867/1992, 877). The transformation of peasants who were attached to rural farms into proletariat workers in urban factories led to large-scale internal migration in European countries during the era of capitalist industrialisation. Such mass internal rural-to-urban migration has taken place in less developed countries since the 1980s' neoliberal globalisation. A capitalist world-system is underpinned by the international division of labour, with nation-states proactively working with domestic and transnational capitalists to pave ways for capital accumulation (Wallerstein 2004). Since the massive outsourcing of manufacturing in the late 1970s, the cheap labour force in the capitalist global production chain is mainly formed by rural migrants in newly emerging countries as these countries become active players in neoliberal globalisation. For instance, thousands of millions of rural migrants have flooded to urban areas in countries such as China and India. ${ }^{6}$ With hopes of improving living conditions, most rural migrants end up working in sweatshops of transnational corporations and low-income service sectors, fulfilling the demand for cheap labourers for both domestic and transnational capital.

In parallel with transnational migration, internal migration involves noticeable material disparity and class division among privileged and underprivileged migrants, while the latter are frequently captured by domestic mainstream media as undesirable and alienated others in urban cities, and the former's integration as new residents is taken for granted. The following discussion takes globalising China as an exemplary case.

When Covid-19 broke out in Wuhan in mid-January, during the critical period of Chunyun ${ }^{7}$ in China the hyper-transmissibility of the disease and a large number of populations on the move made it extremely challenging to control the spread of the novel coronavirus. By 2019, there was a migrant population of around five million in Wuhan: about two-thirds were migrant workers from rural villages and towns in Hubei and several other provinces, and the rest were mostly college students from other provinces attending universities in Wuhan ${ }^{8}$. It was estimated that there were fifteen million passenger trips by bus, train, air, and ship in Wuhan in January, which counted only a

${ }^{6}$ According to the census of India, by 2011 , there were 450 million internal migrants in India: https://censusindia.gov.in/2011census/migration.html

7 Chunyun, the spring festival travel, is known as the largest human migration in the world. It starts 15 days before the spring festival and lasts for 25 more days, making a total of 40 days.

8 The National Health Commission of China published a report on the migrant population census of Wuhan in early 2020:

http://www.ldrk.org.cn/rsf/site/nmpw/zonghexinxi/info/2020/76737.html 
small segment of the total trips during Chunyun. According to the statistics published by the Ministry of Transport of China, in 2019, the number of people travelling during Chunyun surpassed 0.4 billion and passenger trips reached 3 billion. ${ }^{9}$ Chunyun serves as a temporal epitome of class-divided internal migration in China. The three types of travel of Chunyun consist of home visiting, college students on vacation, and tourism. While the majority of home-visiting people are rural migrant workers, the middle class constitutes the tourist population.

Among the 244-million-strong migrant population in contemporary China, $70 \%$ are rural migrant workers and the remaining $30 \%$ are college students and those who settle in Chinese metropolitan cities after graduation from universities. In the "China migrant dynamic survey" conducted by the National Health Commission of China, the mobile population is categorised by the Chinese government into rural migrant workers who form the low-skilled labour force, and migrants with developed human capital. ${ }^{10}$ Such a distinction made by the official discourse shows that the internal migrant population in China is highly divided by class: this is one of the symptoms of China's post-1980s social stratification and structural inequality. The working-class migrant population is mostly constituted by rural migrant workers while the middle-class counterpart is formed by university graduates who settle in the cities where they attended college. Chinese universities are clustered in metropolitan cities and several provincial capitals, including Beijing, Shanghai, Guangzhou, Xi'an, Wuhan, Chengdu, and so on. Each year, millions of students attend colleges in these cities and the majority are non-locals. After graduation, these students take on white-collar, professional jobs; and, especially those graduating from prestigious universities, are more often able to land well-paid jobs, becoming middle-class or even upper-middle-class migrants in the big cities.

Due to the severely uneven distribution of education recourses, children from urban middle-class families receive far more resources and support than their peers from working-class and rural families. From kindergarten to high school, children from affluent families enjoy high-quality education and numerous opportunities for extra curriculum activities, and they are much more likely to be admitted to high-ranking universities. Since the economic reform in the 1980s, the state has divested itself of public service in rural areas and the rural population has been deprived of quality medical care and schooling (Day 2013). Except for a small group of talented children who are fortunate enough to be accepted by prestigious universities after extremely diligent study, millions of rural teenagers drop out of schools and migrate to cities, fulfilling the demand for cheap labour forces in the industrial and service sectors.

China's economic reform has driven over 200 million rural migrants to seek a living in urban areas since the 1980s. The uneven distribution of education, along with other structural factors including the shrinking agricultural economy, the rising market economy, and policy-driven rural-urban divisions has resulted in the proletarianisation of Chinese rural migrants. The integration of China into capitalist globalisation as the "world factory" manifests what Westra $(2018,17)$ describes as "the wholesale linking of China to the seemingly unending fortunes of transnational capital". The state, domestic, and transnational capital conspire to make profits from the surplus-value of rural migrant workers' labour. The country's economic growth miracle rests upon the exploitation of rural migrants as the driving engine of capital accumulation.

${ }^{9}$ Chinese news reports on numbers of travels in Wuhan and nationwide during Chunyun in 2020 and 2019: http://www.whtv.com.cn/p/17571.html; http://www.bjnews.com.cn/news/2019/03/01/551677.html

10 National Health Commission of China has conducted the China migrant dynamic survey on China's internal mobile population since 2009: http://www.chinaldrk.org.cn/wjw/\#/home 
Chinese mainstream media further reinforce rural migrant workers' inequality by creating the arbitrary distinction between rural migrants and urban residents which degrades the former as undesirable and alienated others. Popular discourse, accompanied by official and commercial media discourse, stigmatises rural migrants as a "low quality" population (Jacka 2009; Yan 2008). A dichotomised 'victim' and 'hero' theme in mainstream media representation sidesteps the structural inequality that rural migrants face. For instance, Party media promote individual rural women migrants who become successful entrepreneurs as role models (Sun 2004), underpinning the country's national agenda of economic development through nurturing neoliberal individuals. Compassionate journalism constructs rural women migrants as victims of rape, domestic violence, or human trafficking (2004). Through arousing sympathy, commercial media commodify rural migrants' sufferings as a selling point to appeal to urban readers.

The large-scale internal migration is the inevitable outcome of the relentlessly uneven development and allocation of resources between the eastern coastal areas and the rest of China, between metropolitan and capital cities and small towns and rural villages. Migrating to prosperous urban areas is a means for both the underprivileged rural population and privileged urban groups to pursue the life they desire. But the possibility for migrant populations to have their desirable life is greatly circumscribed by the structural inequality deeply rooted in China's development process in its ongoing economic reform. Conspicuous material disparity and different life circumstances exist among the class-divided migrant groups. Privileged migrants with decent and well-paid jobs enabling them to enjoy middle-class or even extravagant lifestyles easily become new residents of the cities where they settle. Deprived rural migrants, working in sweatshop conditions with little gain, and facing discrimination and exclusion, struggle to survive in cities. This striking disparity epitomises what Goodwin describes as the "real social divisions among wage earners - foremen and those they manage, skilled and unskilled, blue and white-collar, etc.", and the existence of such divisions is "one important set of factors which Marxists from Marx onwards identified as holding back the development of revolutionary or socialist consciousness by the working class" (2018, 541).

The ways that Chinese mainstream media represent migrant populations strengthen such divisions. Privileged migrants' smooth integration and underprivileged migrants' exclusion are underpinned by their class division. Stereotypical, discriminatory, or sympathetic media discourses each fail to recognise the value that rural migrant workers produce and the brutal exploitation from which they suffer. Perpetuating the inequality in the process of migration along with capitalist development, mainstream media belong to what Fuchs $(2018,525)$ critiques as "means of communication significant to capitalist accumulation".

\section{Digital Media in Underprivileged Migrants' Resistance and Activism}

A critical (Marxist) political economic approach also searches for the actual and potential role of media and digital technologies in social struggles and the establishment of alternatives (Fuchs 2014). In the past decade, digital media have played an increasingly significant role in facilitating underprivileged migrants' activism and resistance. Recently, scholarly attention has increasingly focused on the possibility of digital media to enhance the opportunities for underprivileged and disadvantaged migrant groups to express themselves and demand rights. For example, the Dreamer project launched by undocumented immigrants in the US proactively relies on the Internet and social media to advocate rights (Orgad 2012). Against the backdrop that refugees often suffer 
from negative portrayals in media such as the widely circulated discourse of the socalled "European refugee crisis" (Heidenreich et al. 2019; Smets and Bozdag 2018), refugees rely on social media and digital technologies to enhance their visibility in public space as a way of engaging in political action (Nikunen 2019; Jumbert, Bellanova and Gellert 2018). In China, migrant workers resort to social media to mobilise and organise collective actions against the brutal exploitation within factories owned by transnational corporations (Qiu 2016). Migrant worker NGOs deploy the Internet and social media to produce alternative forms of media to promote equality and justice (Yin 2018). In Hong Kong and Singapore, digital media also have a prominent presence in NGO advocacy for migrant domestic workers' rights (Dencik and Wilkin 2015).

But at the same time, digital media are sites of power struggles where underprivileged migrant groups are often subject to dominant political and economic powers. For instance, the enhanced visibility of refugees paradoxically exposes them to surveillance and control (Latonero and Kift 2018). To what extent digital media can promote structural changes towards equality and justice requires careful examination in specific political-economic and socio-cultural contexts. Refugees' self-representation does not necessarily lead to their recognition in Europe, nor does it guarantee any concrete changes to improve their living conditions (Georgiou 2018). While social media facilitate the creation of worker-generated content in Chinese rural migrant workers' activism, commercialised user-generated content still prevails in online space (Qiu 2016). Compared with market-oriented and entertainment media, migrant workers' non-profit and pro-change alternative media have attracted scarce attention even from migrant workers themselves, let alone the general public (Yin 2018). As Fuchs (2014, 61) reminds us, "commercial social media's democratic and political potentials should not be overestimated. Not technologies, but people living under certain social conditions and power relations make rebellions and revolutions".

The formation of counter-hegemonic force should thus start with people. To contest the inequality of underprivileged migrants, occupying a workers' standpoint has significant political implications. Mainstream media and politicians' warnings about the threat of refugees to European countries completely omits the fact that refugees become "a massive reserve army of labour" vulnerable to exploitation (Khiabany 2016, 760). Refugees' self-presentations in the online campaigns in Finland emphasise the deservingness of refugees as humans and loyal citizens, which, as Nikunen (2019) argues, inevitably falls into the hegemonic discourse. A workers' standpoint can go beyond the nationalist and humanitarian discourse, inquire into the political economic conditions of refugees, and form a collective counter-power against capital and capitalist nationstates. Emphasising underprivileged migrant groups' identity as workers is a starting point to politicise the understanding of migrants as labour subjects and to recognise their labour power. For instance, many countries have not incorporated domestic work, mainly performed by working-class migrant women, into national labour laws and thus granting domestic work as formal employment in the labour sector has been a key struggle for the worldwide domestic worker movement in the past decades (Dencik and Wilkin 2015). While mainstream discourse highlights the migrant identity of disenfranchised migrants, which reinforces their stereotypical images as alienated others, a subjective position of workers can transcend the discursive hegemonic power of nationalism and capitalism. To target capitalism rather than migration as problematic is imperative to form broader alliances between migrant workers and local workers for their labour rights and political and economic equality. 


\section{Conclusions}

Capitalism has merged with racial hierarchy and patriarchy in its historical development and global expansion, which has created a huge disparity among migrant populations. Striving for equality and justice for underprivileged migrants requires the contesting of mainstream media to change the public perception of migration from a binary view of migrants as either threats or assets to understanding migration as an intrinsic part of capitalist uneven development and globalisation. A Marxist political economic critique necessitates an epistemological shift to viewing not migration but capitalism as a problem to be solved. Non-profit alternative forms of media, aiming towards transforming unequal power structures, could serve as one of the means to cultivate the political subjectivity of being workers among underprivileged migrants and to form transnational solidary from an anti-capitalist standpoint.

\section{References}

Ahmed, Rukhsana and Luisa Veronis. 2017. Multicultural Media Use and Immigrant Settlement: A Comparative Study of Four Communities in Ottawa, Canada. Journal of International Migration and Integration 18 (2) 587-612.

Anderson, Bridget. 2004. Just Another Job? The Commodification of Domestic Labour. In Global Woman: Nannies, Maids, and Sex Workers in the New Economy, edited by Barbara Ehrenreich and Arlie Russell Hochschild, 104-114. New York: Metropolitan Books/Henry Holt and Co.

Basok, Tanya. 2003. Mexican Seasonal Migration to Canada and Development: A Community Based-comparison. International Migration 41 (2): 4-25.

Bauder, Harald. 2008. Immigration Debate in Canada: How Newspapers Reported, 19962004. Journal of International Migration and Integration 9 (3): 289-310.

Bauder, Harald. 2006. Labour movement: How Migration Regulates Labour Markets. New York: Oxford University Press.

Campani, Giovanna. 2001. Migrants and Media: The Italian Case. In Media and Migration: Constructions of Mobility and Difference, edited by Russell King and Nancy Wood, 38-52. London: Routledge.

Castles, Stephen, Hein de Haas, and Mark J Miller. 2014. The Age of Migration: International Population Movements in the Modern World. New York: The Guilford Press.

Constable, Nicole. 2017. Maid to Order in Hong Kong: Stories of Migrant Workers [second edition]. Ithaca, NY: Cornell University Press.

Croucher, Stephen M., Deepa Oommen, and Emily L. Steele. 2009. An Examination of Media Usage among French-Muslims. Journal of Intercultural Communication Research 38 (1): 41-57. doi: 10.1080/17475750903478113.

Day, Alexander F. 2013. The Peasant in Postsocialist China: History, Politics, and Capitalism. Cambridge: Cambridge University Press.

Dencik, Lina and Peter Wilkin. 2015. Worker Resistance and Media Challenging Global Corporate Power in the 21st Century. New York: Peter Lang.

Fleras, Augie. 2009. Theorizing Multicultural Media as Social Capital: Crossing Borders, Constructing Buffers, Creating Bonds, Building Bridges. Canadian Journal of Communication 34: 725-729.

Fuchs, Christian. 2020. Communication and Capitalism: A Critical Theory. London: University of Westminster Press.

Fuchs, Christian. 2018. Karl Marx \& Communication @ 200: Towards a Marxian Theory of Communication. tripleC: Communication, Capitalism \& Critique 16 (2): 518-534. Accessed July 8, 2020. https://www.triple-C.at/index.php/tripleC/issue/view/42 
Fuchs, Christian. 2014. Critique of the Political Economy of Informational Capitalism and Social Media. In Critique, Social Media and the Information Society, edited by Christian Fuchs and Marisol Sandoval, 51-65. New York: Routledge.

Fudge, Judy. 2011. Global Care Chains, Employment Agencies, and the Conundrum of Jurisdiction: Decent Work for Domestic Workers in Canada. Canadian Journal of Women and the Law 23 (1): 235-264.

Gale, Peter. 2004. The Refugee Crisis and Fear Populist Politics and Media Discourse. Journal of Sociology 40 (4) 321-340.

Georgiou, Myria. 2018. Does the Subaltern Speak? Migrant Voices in Digital Europe. Popular Communication 16 (1): 45-57. doi: 10.1080/15405702.2017.1412440

Georgiou, Myria. 2013. Media and the City: Cosmopolitanism and Difference. Cambridge: Polity.

Georgiou, Myria. 2006. Diaspora, Identity and the Media: Diasporic Transnationalism and Mediated Spacialities. Cresskill, NJ: Hampton Press.

Goodwin, Peter. 2018. Where's the Working Class? tripleC: Communication, Capitalism \& Critique 16 (2): 535-545. Accessed July 3, 2020. https://www.triple-c.at/index.php/tripleC/issue/view/38

Grandea, Nona, and Joanna Kerr. 2010. 'Frustrated and displaced': Filipina domestic workers in Canada. Gender \& Development 6 (1): 7-12. doi: 10.1080/741922629

Gutiérrez Rodríguez, Encarnación. 2018. The Coloniality of Migration and the "Refugee Crisis": On the Asylum-Migration Nexus, the Transatlantic White European Settler Colonialism-Migration and Racial Capitalism. Refuge: Canada's Journal on Refugees 34 (1): 1628. https://doi.org/10.7202/1050851ar

Hardt, Michael and Toni Negri. 2018. The Multiplicities Within Capitalist Rule and the Articulation of Struggles. tripleC: Communication, Capitalism \& Critique 16 (2): 440-448. Accessed July 30, 2020. https://www.triple-c.at/index.php/tripleC/article/view/1025/1195

Hargreaves, Alec. 2001. Media Effects and Ethnic Relations in Britain and France. In Media and Migration: Constructions of Mobility and Difference, edited by Russell King and Nancy Wood, 23-37. London: Routledge.

Harvey, David. 2018. Universal Alienation. triple C: Communication, Capitalism \& Critique 16 (2): 424-439. Accessed August 15, 2020. https://www.triple-c.at/index.php/tripleC/article/view/1026/1193

Harvey, David. 2007a. Neoliberalism as Creative Destruction. The ANNALS of the American Academy of Political and Social Science 610 (1): 21-44.

Harvey, David. 2007b. A Brief History of Neoliberalism. New York: Oxford University Press.

Harvey, David. 1989. The Condition of Postmodernity: An Enquiry into the Origins of Cultural Change. Cambridge, MA: Blackwell.

Hegde, Radha Sarma. 2016. Mediating Migration. Cambridge: Polity.

Heidenreich, Tobias, Fabienne Lind, Jakob-Moritz Eberl and Hajo G Boomgaarden. 2019. Media Framing Dynamics of the 'European Refugee Crisis': A Comparative Topic Modelling Approach. Journal of Refugee Studies 32 (Special issue 1): i172-i182, https://doi.org/10.1093/irs/fez025

Hochschild, Arlie Russell. 2014. Global Care Chains and Emotional Surplus Value. In Justice, Politics, and the Family, edited by Daniel Engster and Tamara Metz, 130-146. New York: Routledge.

Jacka, Tamara. 2009. Cultivating Citizens: Suzhi (Quality) Discourse in the PRC. positions: asia critique 17 (3): 523-535.

Jumbert, Gabrielsen Maria, Rocco Bellanova and Raphaël Gellert. 2018. Smart Phones for Refugees: Tools for Survival, or Surveillance? PRIO Policy Brief 4. Oslo: PRIO.

Kapiszewski, Andrzej. 2016. Arab versus Asian migrant workers in the GCC countries. In South Asian Migration to Gulf Countries: History, Policies, Development, edited by Prakash C. Jain and Ginu Zacharia Oommen, 46-70. London: Routledge India. 
Katz, Vikki S. 2010. How Children of Immigrants Use Media to Connect Their Families to the Community. Journal of Children and Media 4 (3): 298-315. doi:

$10.1080 / 17482798.2010 .486136$

Khiabany, Gholam. 2016. Refugee Crisis, Imperialism and Pitiless Wars on the Poor. Media, Culture \& Society 38 (5): 755-762. doi: 10.1177/0163443716655093

King, Russell and Nancy Wood, eds. 2001. Media and Migration: Constructions of mobility and difference. London: Routledge.

Koh, David. 2020. Migrant Workers and COVID-19. Occupational and Environmental Medicine 77: 634-636.

Latonero, Mark and Paula Kift. 2018. On Digital Passages and Borders: Refugees and the New Infrastructure for Movement and Control. Social Media + Society 4 (1): n.p. https://doi.org/10.1177/2056305118764432

Lawlor, Andrea and Erin Tolley. 2017. Deciding Who's Legitimate: News Media Framing of Immigrants and Refugees. International Journal of Communication 11: 967-991.

Marti, Gabriela. 2019. The Effects of Multilevel Governance on the Rights of Migrant Domestic Workers in Singapore. Journal of Ethnic and Migration Studies 45 (8): 1345-1360. doi: 10.1080/1369183X.2018.1441614

Marx, Karl. 1867/2013. Capital: A Critical Analysis of Capitalist Production: Volume One translated by Samuel Moore and Edward Aveling with an introduction by Mark G. Spencer. Hertfordshire: Wordsworth Editions Ltd.

Marx, Karl and Friedrich Engels. 1848/1992. The Communist Manifesto. New York: Oxford University Press.

Mosco, Vincent. 2009. The Political Economy of Communication. London: SAGE Publications Ltd.

Mummery, Jane and Debbie Rodan. 2007. Discursive Australia: Refugees, Australianness, and the Australian public sphere. Continuum: Journal of Media \& Cultural Studies 21 (3): 347-360.

Nikunen, Kaarina. 2019. Once a Refugee: Selfie Activism, Visualized Citizenship and the Space of Appearance. Popular Communication 17 (2): 154-170, doi: 10.1080/15405702.2018.1527336

Ong, Aihwa. 2006. Neoliberalism as Exception: Mutations in Citizenship and Sovereignty. Durham, NC: Duke University Press.

Orgad, Shani. 2012. Media Representation and the Global Imagination. Cambridge: Polity.

Qiu, Jack Linchuan. 2016. Goodbye iSlave: A Manifesto for Digital Abolition. Champaign, IL: University of Illinois Press.

Romero, Mary. 2013. Nanny Diaries and Other Stories: Immigrant Women's Labor in the Social Reproduction of American Families. Revista de Estudios Sociales 45: 186-197.

Smets, Kevin and Cigdem Bozdag. 2018. Representations of Immigrants and Refugees: News Coverage, Public Opinion and Media Literacy. Communications: The European Journal of Communication Research 43 (3): 293-299. https://doi.org/10.1515/commun2018-0011

Sun, Wanning. 2004. Indoctrination, Fetishization, and Compassion: Media Constructions of the Migrant Woman. In On the move: Women in Rural-to-urban Migration in Contemporary China, edited by Arianne M Gaetano and Tamara Jacka, 109-128. New York: Columbia University Press.

van Dijk, Teun. 2000. New(s) Racism: A Discourse Analytical Approach. In Ethnic Minorities and the Media: Changing Cultural Boundaries, edited by Simon Cottle, 33-49. Philadelphia: Open University Press.

Wallerstein, Immanuel. 2004. World-Systems Analysis: An Introduction. Durham, NC: Duke University Press.

Westra, Richard. 2018. Social Class in China Today: A Review of The New Emperors: Power and the Princelings in China by Kerry Brown, The Peasant in Postsocialist China: History, Politics, and Capitalism by Alexander F. Day, and Insurgency Trap: Labor Politics in 
Postsocialist China by Eli Friedman. Historical Materialism 26 (4): 194-213. doi: 10.1163/1569206X-00001479

Wong, Diana. 1996. Foreign Domestic Workers in Singapore. Asian and Pacific Migration Journal 5 (1): 117-138. https://doi.org/10.1177/011719689600500106

Yan, Hairong. 2008. New Masters, New Servants: Migration, Development, and Women Workers in China. Durham, NC: Duke University Press.

Yea, Sallie, A. K. M. Mohsin and Debbie Fordyce. 2013. A Thousand and One Days: Stories of Hardship from South Asian Migrant Workers in Singapore. Singapore: Banglar Kantha Publications.

Yin, Hang. 2013. Chinese-language Cyberspace, Homeland Media and Ethnic Media: A Contested Space for Being Chinese. New Media \& Society 17 (4): 556-572.

Yin, Siyuan. 2018. Alternative Forms of Media, ICTs, and Underprivileged Groups in China. Media, Culture \& Society 40 (8): 1221-1236. https://doi.org/10.1177/0163443718754653

Yoon, Kyong. 2018. Multicultural Digital Media Practices of 1.5-generation Korean Immigrants in Canada. Asian and Pacific Migration Journal 27 (2): 148-165.

\section{About the Author}

Siyuan Yin

Siyuan Yin is an assistant professor at the School of Communication at Simon Fraser University. Siyuan's research areas include critical cultural studies, feminisms, political economy of communication, and China studies. Her research projects explore inequalities and resistance in the process of migration and globalisation, with a particular focus on migrant workers and mediated activism. Siyuan also studies gender and class politics and feminist movements in China. 